\author{
R. Strelchuk, O. Shelkovyi, Kharkiv, Ukraine
}

\title{
EDM GAP MODELING AT ELECTRICAL DISCHARGE GRINDING WITH CHANGE OF ELECTRIC POLARITY
}

\begin{abstract}
The paper presents an experimental study and modeling in the Simulink graphical environment of the EDM gap at electrical discharge grinding (ED grinding) with change of electric polarit of difficult-to-machine materials. Based on the experimentally obtained oscillograms of currents and voltages in the cutting zone, an EDM gap model has been developed, which implements the nonlinear dependence of the active resistance of the electroerosion gap on its value, which makes it possible to take into account the effect of the interelectrode environment on the parameters of electric discharge pulses. Comparison of the calculated oscillograms obtained in the Simulink model with the experimental ones has shown that during ED grinding, the developed EDM gap model adequately reflects the real electrical processes occurring in the electroerosion gap.
\end{abstract}

Keywords: EDM gap, oscillogram of currents and voltages, equivalent circuit, electrical processes

Introduction. The process of interaction of the cutting tool with the surface of the processed material under the conditions of electrical discharge grinding with change of electric polarity has not been studied, and the cutting zone of combined processing has not been investigated $[1,2]$. In this regard, the modeling of the process occurring in the cutting zone has been carried out, and the features and patterns of interaction of the cutting tool with the surface of the processed material have been defined in the paper.

Literature Review. The machining zone for ED diamond grinding is a complex electrophysical system [3,4]. At the same time, it is the place of microcutting and discharge activity in the electroerosion gap. When a voltage is applied, an electric current, which passes through the conductive bridges, the hydraulic fluid, which has a certain electrical conductivity, bridging the electroerosion gap, and through the channel of the resulting discharge during its action, arises in this zone.

The size of the machining zone is determined by the front width of the grinding wheel and the EDM gap value, i.e. the distance between the wheel binder and the surface of the processed material.

In the machining zone, along with chip formation and discharge activity, the complex mechanical and electrophysical processes occur: contact-frictional, thermal, electrical, plasma-chemical, and electrohydraulic ones; high-frequency vibrations and cavitation of the liquid medium take place. The main, dominant effect of electrical energy in the machining zone is manifested in electroerosion processes and phenomena of a combined nature of various duration and intensity.

(C) R. Strelchuk, O. Shelkovyi, 2020 
They occur in the areas of contact and contactless interaction of the wheel with the cut off chips and the processed material, where the surfaces of these electrodes come close to each other and where the contact, the formation of intermittent or tight contacts and their rupture are possible. Thus, the zone of ED diamond grinding is characterized by contact and contactless electric erosion [5].

Research Methodology. The EDM gap model characterizes the electrodynamic processes therein and it is determined by the type and parameters of the equivalent circuit. In order to make a reasonable choice of the type and parameters of the EDM gap model, oscillograms of currents and voltages of technological pulses have been experimentally obtained at various values of this gap (Fig. 1).

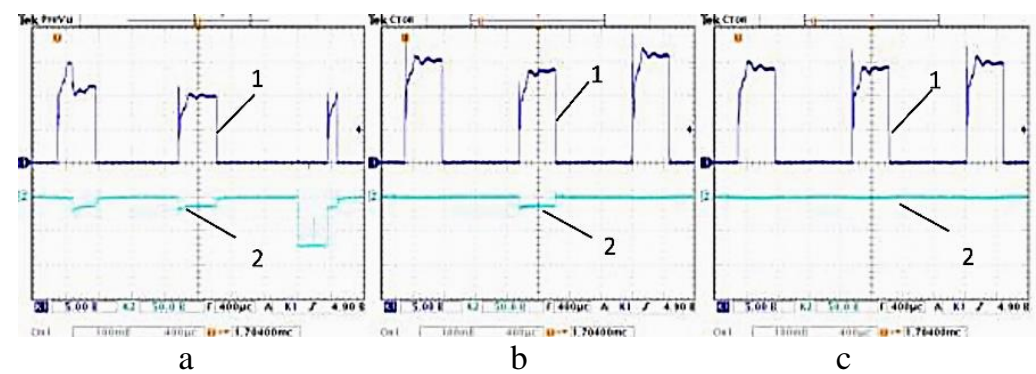

Figure 1 - Oscillograms of currents (1) and voltages (2) in the EDM gap of size: $\mathrm{a}-7 \mu \mathrm{m} ; \mathrm{b}-14 \mu \mathrm{m} ; \mathrm{c}-$ in case of a short circuit

Experimental studies have been carried out on the basis of a ЗД642E machine tool. Additional energy was supplied into the cutting zone from a HO 6506 pulse generator, which converts $380 \mathrm{~V}$ alternating current into a unipolar pulse current. The voltage, discharge current amplitude, frequency and relative pulse duration have been controlled from a pulse generator.

An end-face grinding method has been used, which was carried out with conical cup wheels $12 \mathrm{~A} 2-45^{\circ} 150 \times 10 \times 3 \times 32$ on a binder M1-01 with diamond grains AC6 with a grain size of $100 / 80$ and a concentration of 4 . Before the experiments, the diamond wheels have been pre-straightened and run-in for 5-10 minutes. The processed material was VK6 carbide plates with dimensions of $14 \times 14 \times 5 \mathrm{~mm}$.

Electrical modes of the technological pulse generator: voltage pulse amplitude$50 \mathrm{~V}$, technological pulse frequency- $44 \mathrm{KHz}$, relative pulse duration-1.

The oscillograms have been recorded with a GOS-6050 oscilloscope (Good Will Instrument Co), which was connected according to the diagram shown in Fig. 2.

The size of the electroerosion gap has been recorded by a dial indicator with a graduation of $0.001 \mathrm{~mm}$. Analysis of the electrical circuit of the NO 6506 pulse 
generator and the oscillograms of currents at different EDM gap values makes it possible to go just with the T-shaped equivalent circuit, which takes into account the reactance of the technological pulse generator and the EDM gap.

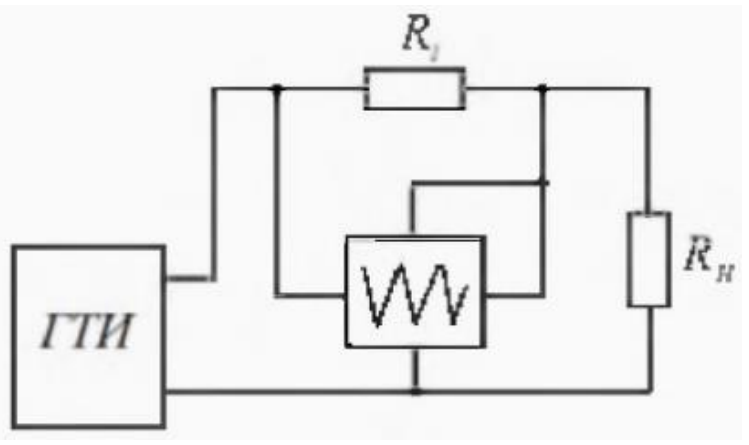

Figure 2 - Oscilloscope connection diagram

Since the current in the EDM gap has a pronounced oscillatory component, the equivalent circuit includes the oscillatory RLC circuit shown in Fig. 3.

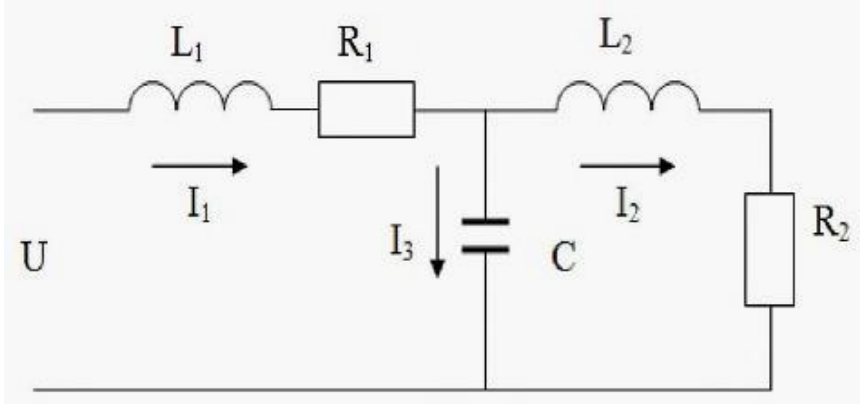

Figure 3 - The equivalent circuit of electroerosion gap

The active resistances of the technological pulse generator $R_{l}$ and the load (electroerosion gap) $R_{2}$ can be found by the established values of the voltage drop $U_{2}$ across the resistance $R_{2}$ and the current $I_{2}$ at a known value of the amplitude of the no-load pulses of the generator $U$ :

$$
R=\frac{U-U_{2}}{I_{1}},
$$




$$
R_{2}=\frac{U_{2}}{I_{2}} \text {. }
$$

As a result of oscillograms processing, the values of active resistances $R_{l}$ and $R_{2}$ have been obtained for different EDM gap values (Table 1).

Table 1 shows that the resistance of electroerosion gap $R_{2}$ nonlinearly depends on the EDM gap value $S$. Since at a given generator voltage $U$, there is a limiting value of the electroerosion gap $S$, at which an electric discharge does not occur, the indicated dependence $R_{2}=f(S)$ can be approximated by the expression:

$$
R_{2}=\frac{k s}{t-s} \text {. }
$$

where $k$ to $t$ approximation coefficients found by the least square method [6], depending on the amplitude of the operating pulse generator and the electrical parameters of the equivalent circuit.

Table 1 - Active resistance values

\begin{tabular}{|c|c|c|}
\hline EDM gap $S, \mu \mathrm{m}$ & $R_{1}, \mathrm{Ohm}$ & $R_{2}, \mathrm{Ohm}$ \\
\hline 14 & 4.85 & 2.21 \\
\hline 7 & 4.85 & 0.35 \\
\hline Short circuit & 4.85 & 0 \\
\hline
\end{tabular}

In order to determine the remaining parameters of the equivalent circuit, namely, $L_{1}, L_{2}$, and $C$, the coordinates of several characteristic points have been found on the experimentally taken oscillograms of the transient process of a single electric discharge. Parametric identification of the oscillogram (Fig. 4) was digitized in the GetDataDigitizer program.

$$
\left\{\begin{array}{c}
L_{1} \frac{d I_{1}}{d t}+R_{1} I_{1}+U_{C}=U \\
L_{2} \frac{d I_{2}}{d t}+R_{2} I_{2}=U_{C} . \\
C \frac{d U_{C}}{d t}=I_{1}-I_{2}
\end{array} .\right.
$$

A measure of the adequacy of the experimental data and the calculated values obtained as a result of solving a system (4) is the square of the distance between the experimental and calculated points [7]. 


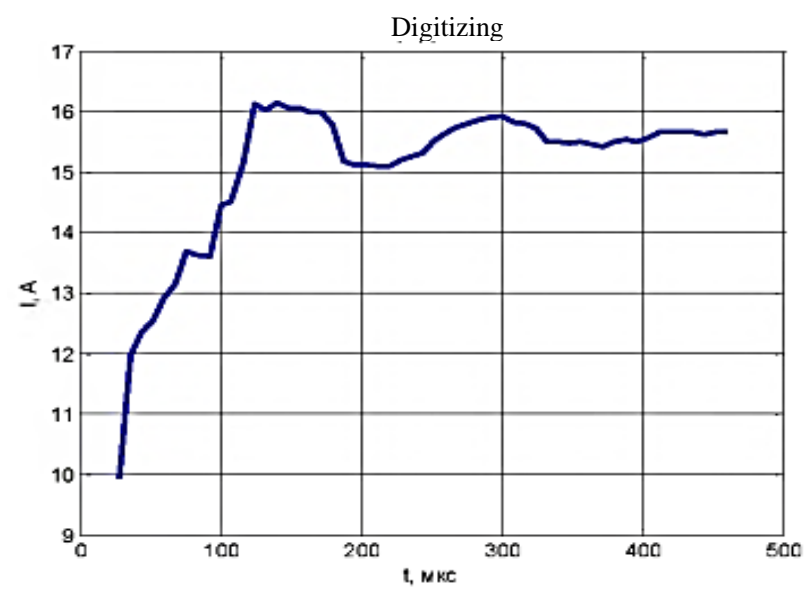

Figure 4 - An example of digitizing a current pulse

$$
F\left(L_{1}, L_{2}, C\right)=\sum_{i=1}^{50}\left(t_{i}-t_{p i}\right)^{2}+\sum_{i=1}^{50}\left(I_{i}-I_{p i}\right)^{2}
$$

Calculated points are also selected at the extreme values of the resulting solution (4). By minimizing $F\left(L_{1}, L_{2}, C\right)$ over the variables $L_{1}, L_{2}$, and $C$, we can determine their value. The minimization has been carried out in the Matlab system using the simplex Nelder-Mead method [8]. As a result, the following values of the sought parameters of the equivalent circuit averaged over the entire series of experiments have been obtained: $L_{l}=173 \mu \mathrm{H}, L_{2}=173 \mu \mathrm{H}$, and $C=18 \mu \mathrm{F}$.

Results. Fig. 5 shows the calculated curve obtained as a result of minimizing the solution (4) by criterion (5) and the experimental curve taken from the graph Fig. 1b, confirming good agreement between the calculated and experimental results.

Based on the accepted type and the found parameters of the EDM gap equivalent circuit, the EDM gap model has been developed for ED diamond grinding in the Simulink graphical simulation environment. The block diagram of the model is shown in Fig. 6.

Simulink model of EDM gap includes two blocks "B1" and "B2". Block 1 ("B1") reproduces the dependence of the EDM gap resistance on its value, block 2 ("B2") simulates the operation of the equivalent circuit (Fig. 7.). 


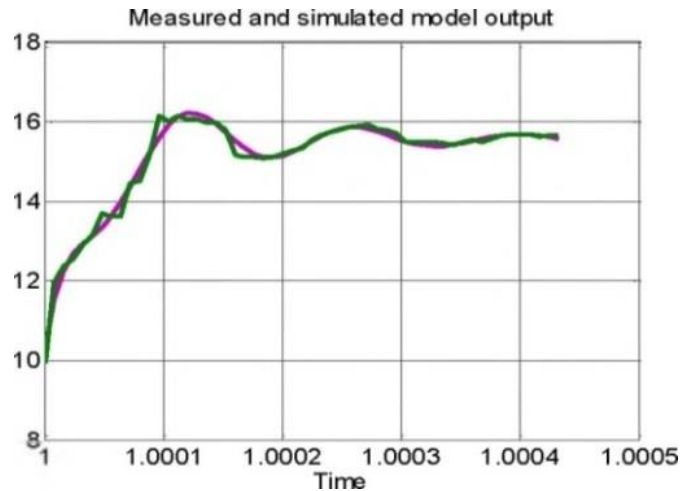

Figure 5 - Calculated and experimental values of current change in EDM gap

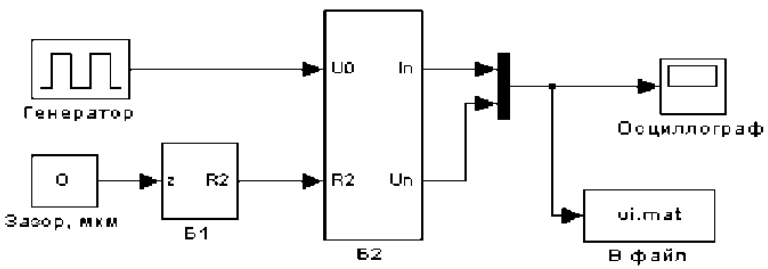

Figure 6 - Block diagram of a Simulink model of EDM gap

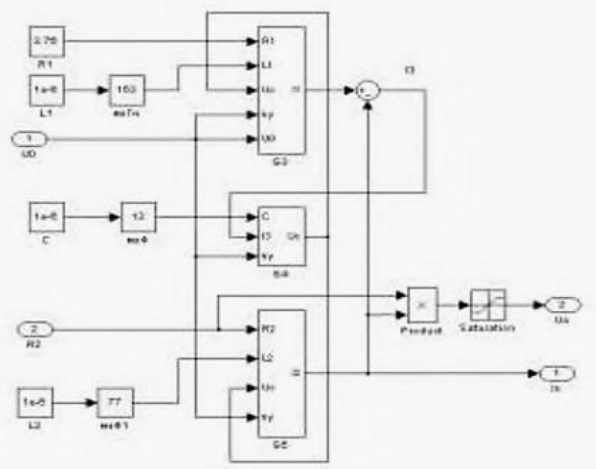

Figure 7 - Blocks of the Simulink model of the EDM gap 
Fig. 8 shows oscillograms of currents and voltages obtained in the developed Simulink model of the EDM gap.

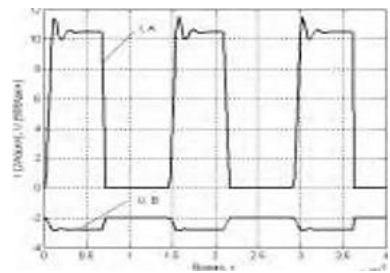

a

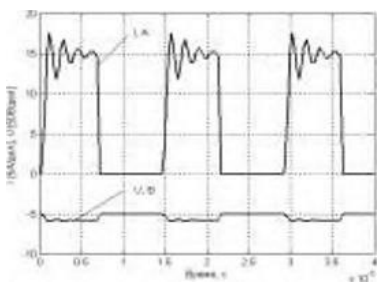

$\mathrm{b}$

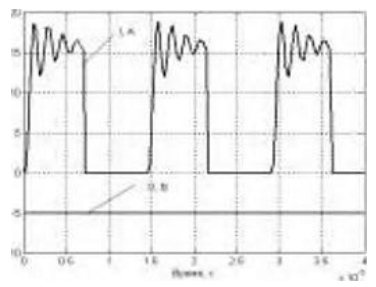

c

Figure 8 - Oscillograms of currents and voltages obtained in the Simulink model of the EDM gap at: $\mathrm{a}-7 \mu \mathrm{m} ; \mathrm{b}-14 \mu \mathrm{m} ; \mathrm{c}-$ in case of a short circuit

Emergence of a current pulse at the initial moment of time on the calculated oscillograms is due to the capacitance of the gap between the diamond wheel and the surface of the processed material before the discharge occurs. The presence of this capacitance in the experiment is not taken into account, since it practically does not affect the ED grinding process.

Conclusions. Thus, as a result of the analysis of the experimental oscillograms of the operating pulse currents, it was found that the electrical processes occurring in the EDM gap during ED grinding are of an oscillatory nature. The environment in which these processes take place can be represented with sufficient accuracy in the form of a T-shaped equivalent circuit, which includes active resistances, inductances, and capacitance. It was found that the active resistance of the EDM gap nonlinearly depends on its value. The root-meansquare deviation between the calculated and experimental pulses of current and voltage, referred to its established value, does not exceed $12-15 \%$.

The found values of equivalent circuit parameters made it possible to obtain the Simulink model of the EDM gap for ED grinding.

The good agreement of the calculated oscillograms obtained in the Simulink model with the experimental ones has shown that the developed EDM gap model for ED grinding adequately reflects the real electrical processes occurring in the EDM gap.

References: 1. Strelchuk R.M., Uzunian M.D. Sposib elektroeroziinoho almaznoho shlifuvannia zi zminnoiu poliarnistiu elektrodiv, Patent UA, no. 131894, 2019. 2. Arun, I., Yuvaraj, C., Jyothibabu, P. Influence of Silica on Microstructural Modification of Electrical Discharge Composite Coating and its Wear Performance // Silicon 12, p. 2375-2386 (2020). 3. Montes, J., Cuevas, F., Reina, F. Modelling and Simulation of the Electrical Resistance Sintering Process of Iron Powders // Met. Mater. Int. 26, p. 
1045-1059 (2020). 4. D’Urso, G., Maccarini, G., Ravasio, C. Influence of electrode material in microEDM drilling of stainless steel and tungsten carbide // Int J. Adv. Manuf. Technol. 85, p. 2013-2025 (2016). 5. Giridharan, A., Samuel, G. Investigation into erosion rate of AISI 4340 steel during wire electrical discharge turning process // Machining Science and Technology, p. 287-298, (2018). 6. Sukhov A .N. Matematicheskaya obrabotka rezultatov izmerenij. - Moscow: MISI, 1982. - 89 p. 7. Tarasik V. P. Matematicheskoe modelirovanie tekhnicheskikh sistem. - Minsk: DizajnPRO, $2004-$ 640 p. 8. R.Andreani, G.Haeser, J.M.Martínez // On sequential optimality conditions for smooth constrained optimization, Optimization 60 (2011), pp. 627-641.

\title{
Роман Стрельчук, Олександр Шелковий, Харків, Україна \\ МОДЕЛЮВАННЯ МІЖЕЛЕКТРОДНОГО ЗАЗОРУ ПРИ ЕЛЕКТРОЕРОЗІЙНОМУ ШЛІФУВАННІ ЗІ ЗМІНОЮ ПОЛЯРНІСТЮ ЕЛЕКТРОДІВ
}

\begin{abstract}
Анотація. У статті проведено експериментальне дослідження та моделювання в графічному середовищі Simulink межелектродного зазору при електроерозійному шліфуванні зі змінною полярністю електродів важкооброблюваних матеріалів. Проведено моделювання процесу, що відбувається в зоні різання, і встановлено особливості та закономірності взаємодії різального інструменту $з$ поверхнею оброблюваного матеріалу деталі. Розроблена модель межелектродного зазору дозволяє характеризувати електроерозійні процеси, щчо протікають в зоні шліфування, $i$ вона визначалася типом $i$ параметрами схеми заміщення. 3 а експериментально отриманими осцилограмами струмів $i$ напруг в зоні різання розроблена модель межелектродного зазору, що реалізує нелінійну залежність активного опору міжелектродного проміжку від його величини, яка дозволяє враховувати вплив міжелектродного середовища на параметри електророзрядних імпульсів. Порівняння розрахункових осиилограм, отриманих в Simulink-моделі, з експериментальними, показало щчо розроблена модель межелектродного зазору при електроерозійному шліфуванні досить адекватно відображає реальні електричні прочеси, що протікають в міжелектродному проміжку. В результаті аналізу експериментальних осиилограм струмів робочих імпульсів було встановлено, що електричні процеси, що протікають в міжелектродному зазорі при електроерозійному шліфуванні носять коливальний характер. Середовище, в якому протікають иі процеси може бути з достатньою точністю представлено у вигляді Т-подібної схеми заміщення, щио включає в себе активний опір, індуктивності та ємність. Середньоквадратичне відхилення між розрахунковими і експериментальними імпульсами струму і напруги, віднесене до його сталого значення, не перевищує $12-15 \%$.
\end{abstract}

Ключові слова: міжелектродний зазор; осиілограмма струму i напруги; схема заміщення; електричні прочеси; зона різання. 